\title{
Impact of Internal Marketing on Job Satisfaction and Organizational Commitment: A Study of Teaching Hospitals in Saudi Arabia
}

\author{
Ala'Eddin Mohammad Khalaf Ahmad \\ Assistant Professor of Marketing, Faculty of Economics and Administration \\ King Abdulaziz University, Jeddah, Kingdom of Saudi Arabia \\ Tel: 966-56-852-7444Ｅ-mail: amahmed1@kau.edu.sa; aladdin.a.h@hotmail.com \\ Hussein Mohammad Al-Borie \\ Assistant Professor of Health Services Management \\ Faculty of Economics and Administration \\ King AbdulAziz University, Jeddah, Kingdom of Saudi Arabia
}

Received: August 6, 2012

doi:10.5430/bmr.v1n3p82
Accepted: August 30, $2012 \quad$ Online Published: September 1, 2012

URL: http://dx.doi.org/10.5430/bmr.v1n3p82

This research was supported under Faculty of Economics and Administration-King Abdulaziz University-funding scheme.

\begin{abstract}
The purpose of this research is to examine the impact of internal marketing on job satisfaction and organizational commitment of the teaching hospitals in Kingdom of Saudi Arabia. The independent variables are internal marketing factors was represented by these variables namely selection and appointment, training and development, organizational support, incentives and motivation, and retention policy. The dependent variables were represented by and job satisfaction and organizational commitment. A structured questionnaire was distributed to a sample of 250 physicians representing all of the teaching hospitals in Saudi Arabia. This study was used the multiple regression analysis to show the impact of internal marketing on job satisfaction and organizational commitment. The research's findings showed that internal marketing (selection and appointment, training and development, organizational support, incentives and motivation, and retention policy) had a positive effect on Saudi teaching hospitals physicians' job satisfaction, and organizational commitment. This research will make a positive contribution in the direction of internal marketing factors and its impact on physicians' job satisfaction and organizational commitment in Saudi teaching hospitals in KSA.
\end{abstract}

Keywords: Internal marketing, Physicians' job satisfaction, Organizational commitment, KSA

\section{Introduction}

Services have increasingly assumed a more vital role in the economic growth and development of countries worldwide. The deregulation of services in many nations during the 1980s, especially in the area of services (e.g. health insurance, telecommunication, hotels and hospitality, and health services) has led to a stiff and intensified competition among various businesses (Kameswari and Rajyalakshmi, 2012). Patient's expectation and preferences, technological advances, multi health services providers and huge competition, and business propositions made many service organizations to think of a marketing approach to deliver satisfaction to the customers (Ahmad et al, 2010; Armstrong and Kotler, 2011). Consequently, working in such altering environment requires the accurate sort of staff to survive. It is at this point that the concept of internal marketing and internal customer satisfaction arises. Internal marketing refers to all the actions that an organization (i.e. health care organizations, and hospitals) has to perform in order to develop, train and motivate its employees, so to enhance the quality of the services provided to its customers (Chen et al, 2006). This is important for the teaching hospitals in KSA, because increased customers' satisfaction means the hospital will treat a greater number of patients, which will increase the hospital revenues from the self fund patients and third party payers. Kotler (1991) stated that internal marketing is the task of successfully recruiting, 
educating and motivating employees so as to perfect customer service (Kotler, 1991). Kotler (1994) also mentioned that it is not logical to expect perfect services from an organization, whose employees are not ready to provide such services. Internal marketing is the way to accomplish that (Kotler, 1994). Administering their human resources effectively is very important for organizations that provide services to their customers, because the services generated by the organization are produced by the employees directly for the client (Chen et al, 2006). This necessity led to the development of internal marketing as a distinct field of marketing. In 1970s Berry and his colleagues (Berry et al, 1976) were the first to introduce the concept of internal marketing in the US, based on the traditional marketing mix of 4 Ps (Product, Price, Promotion and Place). They posited that employees can be considered to be internal customers and their jobs could be seen as the organization's products. In the 1980s, Gronroos $(1981,1984)$ argued that employees were an important part of the overall product or service delivered. Therefore, they should be trained as marketers with customer retention skills that would enable the building of ongoing customer relationships. Conduit and Mavondo, based on Gronroos basic idea, divided internal marketing practices into five categories: employees' education, management support, internal communication, human resources and employees' intervention in external communication (Conduit and Mavondo, 2001). Based on these, Rafiq and Ahmed (2000) define IM as "a planned effort using a marketing-like approach to overcome organizational resistance to change and to align, motivate and inter-functionally co-ordinate and integrate employees towards the effective implementation of corporate and functional strategies in order to deliver customer satisfaction through a process of creating motivated and customer-orientated employees".

This study examines the factors which contributes and enhances the adoption of internal marketing concept in Saudi Arabia, and the impact of internal marketing on the job satisfaction and organizational commitment for Saudi teaching hospitals physicians. Findings of this research are useful for the health sector in formulating appropriate internal marketing strategies to build physician satisfaction and organizational commitment.

\section{Literature Review}

\subsection{Internal marketing}

Gronroos (1981), one of the scholars who early introduced the term "internal marketing", defined the term as the behavior of selling a corporation to its internal customers (employees) under the principle that highly satisfied employees will help create a market-oriented and customer-centered corporation and, consequently, encourage employees with customer-oriented awareness (Bernstein, 2005; Longbottom et al, 2006). Greene et al (1994) hypothesized that internal marketing refers to the application of marketing philosophy and methods to employees who serve customers in order to utilize and conserve employees and guarantee they strive to finish tasks and duties. Therefore, the concept of internal marketing notices employees as internal customers and their work as internal "products", and, consequently, dedicates efforts to the design of products that better satisfy employee needs and wants (Longbottom et al, 2006).

Research reveals that the concept and the action of an organization's internal marketing upgrade employee job satisfaction Tansuhaj et al (1991); Rafiq and Ahmed (2000) Conduit and Mavondo (2001) and this in turn improve the organizational performance of the organization (Pfeffer and Veiga (1999); Nebeker et al (2001).

Zeithaml and Bitner (2000) pointed that in the service triangle, the objective of external marketing is to launch commitment, interactive marketing to fulfill commitment, and internal marketing to develop the capability to fulfill commitment. In other words, the three types of marketing in the service triangle are critical to successful service and higher corporate profits. Internal marketing is a communication process, and the purpose is to create the customer-oriented organizational culture (Bernstein, 2005).

Preston and Steel (2002) addressed issues related to internal marketing. They opined that recruiting; training, developing and motivating staff is the important components of internal marketing and felt that it is the external marketing impact of each member of the staff that is the essential focus of an internal marketing strategy. Naude et al (2003) developed three dormant variables that included person, situation, and person $\mathrm{x}$ situation and found that location, age, length of tenure, as well as many interaction variables. Paulin et al (2006) tested a model comparing overall and customer-linked antecedents and consequences of employee affective organizational commitment and indicated that co-worker support and the perception of fair treatment are the precursors of customer-linked job satisfaction.

Che Ha et al (2007) viewed internal marketing as an important concept where firms apply marketing tools to attract and retain the best employees which enhance the business performance. They identified 12 constructs of internal marketing inter-functional coordination and integration, customer orientation, marketing like approach, job 
satisfaction, empowerment, employee motivation, quality of service, employee development, and vision of the organization, strategic reward, internal communication and senior leadership.

Masroor and Fakir (2009) investigated the level of job satisfaction and intent to leave among Malaysian nurses. They suggested that the nursing staffs were moderately satisfied with supervisor, job variety, closure, compensation, co-workers and HRM/management polices and therefore exhibits a perceived lower level of their intention to leave the hospital and the job. Nittala and Kameswari (2009) opined that service organizations need to attract and retain customers to ensure a sustainable competitive advantage as the employee plays a central role in attracting, building and maintaining relationships with customers/patients.

Sang et al (2009) establish that aspects of job satisfaction like reimburse, colleagues, supervisors, working conditions, job security, promotion aspects and the nature of work to be the most researched and stated that all these aspects are positively inter-correlated with job satisfaction.

Panigyrakis and Theodoridis (2009) examined a synthesis of internal marketing and investigated its effect on business performance in a retail context and developed a Structural Equation Model that indicated five dimensions of the internal market construct: formal interaction, reward systems, feedback, internal procedures and policies and internal customer orientation (ICO). Pawan et al (2009) found that monotonous work, stressful work environment, adverse working conditions, and lack of career development opportunities; better job opportunities elsewhere, emerged as the key causes of increasing attrition rates in the Indian call centre industry. Karthikeyan et al (2010) assessed the effectiveness of the various facets of training i.e. employee's attitude towards training inputs; quality of training programmes; application of training inputs to the actual job. Findings indicate that effective training has a direct and positive influence on growth \& result of the organization.

Yavas and Babakus (2010) examined the nature of relationships between six organizational support mechanisms, a personal resource, and selected psychological and behavioral work outcomes. Results show that supervisory support is most closely associated with psychological work outcomes. Yang and Coates (2010) found that reliability; responsiveness, assurance, empathy, communication, consideration, fairness, recognition and flexibility influence the internal service quality of caddy managers in internal service encounters between caddies and caddy managers. Ibrahim et al (2010) identified that the recruitment, development, internal communications, incentives and demographic factors (gender, age, experience and education) have impact on job satisfaction. Khan et al (2011) established a link between perceived internal service quality practices with employee retentions in mediating environment of employee job satisfaction. They identified employee selection, training and development, work design; job description, rewards and compensation have positive and significant dimensionality to internal service quality.

Employees are regarded as corporate partners who assist with firms to provide products and services for external customers. Conduit and Mavondo (2001) divided internal marketing activities into five constructs based on the seven categories proposed by Gronroos (2000), with the five constructs related to one another as revealed in the results of a sample survey (Suzuki et al, 2006). These five constructs are: (1) market training and education; (2) management support; (3) internal communication; (4) personnel management; and (5) employee involvement in external communication. The constructs suggested by Conduit and Mavondo (2001).

Many of the studies highlighted the relation between internal marketing and job satisfaction. The factors of internal marketing like pay, coworker support, supervisors, working conditions, job security, promotional aspects, nature of work, employee selection, employee training and development, work design, job definition employee rewards and compensation, fairness, recognition, flexibility, feedback, quality of service, employee development, vision of the organization, strategic reward, internal communication and senior leadership have been concentrated upon by different authors over the years.

Based on the literature the present study identified five dimensions of internal marketing factors: selection and appointment (staffing), training and development, organizational support, incentives and motivation, and retention policy. These dimensions are studied in the teaching hospitals in Saudi Arabia, to identify their relation to physicians' job satisfaction and organizational commitment. The established relationship from the literature between the various internal marketing dimensions and physicians' job satisfaction and organizational commitment is shown in figure 1.

\subsection{Job Satisfaction and Organizational Commitment}

\subsubsection{Job satisfaction}

Job satisfaction in general refers to the emotions the employee feels about his job, and how he reacts to them (Tadeka, 2005; Shiu and Yu, 2010). Job satisfaction is a broadly studied concept in numerous occupational fields, including 
the health care industry. Nelson (2006) contends that the principal determinant of whether health care employees stay or voluntarily quit a job is dissatisfaction with their employment situation.

Robbins (1996) assumed that job satisfaction stands for the general attitudes that a worker has toward his/her job, with a high level of job satisfaction indicating a positive attitude. Job satisfaction refers to a joyful or positive emotional state regarding work or the work experience (Shimizu et al, 2005; Suzuki et al, 2006). Porter and Lawler's (1968) definition of job satisfaction includes both internal and external satisfaction. From the above definition internal satisfaction refers to the causes that create job satisfaction, and are closely related to the job itself. In other meanings, it is the level of satisfaction achieved through the job itself, through facets such as sense of achievement, growth, self-esteem, independence, and sense of control (Shimizu et al, 2005). On the other hand, external satisfaction, is indirectly related to the job itself, and includes such facets as good working environment, welfare, high salary, promotion, etc.

By joining the factors that influence job satisfaction proposed by scholars, it can conclude the following: Job satisfaction refers to an employee's feelings of, or emotional response to, his or her job and relevant elements (Takeda et al, 2005). Level of satisfaction depends on the difference between actual gains and predictable gains, and can be divided into two constructs: internal satisfaction and external satisfaction (Shimizu et al, 2005; Castle et al, 2007).

The essential concept of internal marketing is to treat employees/physicians at all levels of the organization/hospital as internal customers (Iliopoulos and Vasilios Priporas, 2011). The growing recognition of the importance of the employees'/physicians' role has led service organizations/hospitals to adopt internal marketing and hence, treat their employees as internal customers (Iliopoulos and Vasilios Priporas, 2011). Previous studies showed that internal marketing has a positive effect on job satisfaction.

\subsubsection{Organizational commitment}

The concept of organizational commitment has become a vital research topic in the field of organizational behaviors ever since it was first suggested by Whyte (1956). Porter et al (1974) proposed that organizational commitment is the degree of an individual's identification with, and loyalty to, a specific organization, and includes: (1) value commitment: strong belief in, and acceptance of, organizational objectives and values; (2) effort commitment: willingness to dedicate greater effort to benefit the organization; (3) retention commitment: willingness to remain as a member of an organization (Lambert et al, 2006; Moss et al, 2007). Buchanan (1974) believed that organizational commitment means an individual is attached emotionally to an organization, including identification with, and acceptance of, organizational objectives and values; mental devotion to, and concentration on, a job role; and loyalty to, and affection for, the organization (Dee et al, 2006). Therefore, the concept of organizational commitment embraces the following employee factors: (1) desire to strive to the fullest in order to represent an organization; (2) desire to remain with an organization; (3) feelings of belonging and loyalty to an organization; (4) acceptance of major organizational goals and values; (5) positive evaluation of an organization.

\section{Research Model and Hypotheses}

\subsection{Research Model}

Insert Figure 1 here

\subsection{Research Hypotheses}

1) Internal marketing has a positive significant effect on physician job satisfaction.

2) Selection and appointment has a positive significant effect on physician job satisfaction.

3) Training and development has a positive significant effect on physician job satisfaction.

4) Organizational support has a positive significant effect on physician job satisfaction.

5) Incentives and motivation has a positive significant effect on physician job satisfaction.

6) Retention policy has a positive significant effect on physician job satisfaction.

7) Internal marketing has a positive significant effect on organizational commitment.

8) Physician job satisfaction has a positive significant effect on organizational commitment.

\section{Research Contribution}

This research will make a positive contribution in the direction of internal marketing influences job satisfaction and organization commitment in the health services in Saudi Arabia. The research results can basically help the managers 
of hospitals to project all the aspects of their hospitals, and to focus on internal marketing concept and its variables, which may in turn influence positively the hospital staff satisfaction and organizational commitment, and this ultimately can enhance the overall performance of the targeted hospitals.

\section{Research Aim and Objectives}

The aim of this research is to explore the importance of employees in the teaching hospitals in the KSA in particular the physicians. And to what extent the internal marketing practices related to employees, participate in the sense of job satisfaction and organizational commitment towards their hospitals. Based on the relevant literature of the internal marketing, and job satisfaction and organizational commitment the research objectives are:

- To determine the factors which constitute internal marketing in the Saudi Arabia teaching hospitals?

- To examine the effect of internal marketing on physician job satisfaction in Saudi Arabia teaching hospitals.

- To examine the effect of physician job satisfaction on organizational commitment.

- To examine the effect of internal marketing on organizational commitment.

\section{Research Methodology}

This research is an empirical study that described the nature of the relationship selection and appointment (staffing), training and development, organizational support, incentives and motivation, and retention policy) and job satisfaction and organizational commitment.

\subsection{Measurement}

The questionnaire included perceptual measures that were rated on a five-point Likert scale. Each scale item was anchored at the numeral 1;1 = "strongly disagree"; 5 = "strongly agree". This format has been recommended for management and health services marketing surveys (Elbeck, 1987; Steiber, 1989). The research questionnaire was designed based on previous empirical literatures. The research questionnaire was used as primary data collection method. Multiple items were used to assess their measurement properties (reliability and validity). Consistent with the literature, the scale items selected for the dependent variable were direct measures of job satisfaction with influences received from internal marketing factors as independent variables.

Both the independent and dependent variable(s) deployed in the research are explained in Table 1 and 2 according to the proposed hypotheses.

\subsection{Research Population and Respondents}

\section{The Research Population}

The population of this research consists of the teaching hospitals in the Saudi Arabia. The population in this research is defined as all the teaching hospitals of the Saudi region governorates which are licensed as teaching hospitals by Ministry of Higher Education-KSA.

The number of hospitals included in the research population for this study was five. This research focused on the different multi-ownership teaching hospitals. Hospitals in Saudi are either government hospitals (Ministry of Health, Ministry of Defense, National Guard Hospitals, and university hospitals), and private hospitals.

The hospitals were classified according to the number of available beds: large hospitals (300 beds or more than) medium hospitals (101-299 beds) and small hospitals (100 or less than beds). Although there are a number of classifications for hospital size (American Hospital Association, 1974), the one depending on bed capacity was used because it is the most popular measure internationally (American Hospital Association, 1991).

\section{The Research Respondents}

The research was conducted with all the physicians in Saudi teaching hospitals. These physicians included the following; firstly, Saudi and non-Saudi physicians also the physicians from the different occupational levels (consultant, specialist, and general practitioner).

The researcher gathered 230 out of 250 questionnaires, yielding a response rate of $92 \%$ (Table 6). All data collection procedures were designed to ensure the anonymity. Respondents typically held purposive sample. It should be noted that every questionnaire was personally handed and instructions were given to each physician before completing the questionnaire. Regarding to educational levels of those physicians (70\%) were bachelor degree holders, $(25 \%)$ of them were master degree holders and the remaining (5\%) were doctoral degree holders. In terms of the age group of respondents, it is interested to note that (80\%) of them are fell into (41-50) years, whereas (15\%) fell into (30-40). The respondents nationalities, the majority (80\%) were Saudi and the rest are non-Saudi from different countries 
around the world. Regarding to their experiences in health services organizations the majority of them were (16-20) years which represented (75\%). Regarding to hospital size (90\%) were big hospital, (10\%) middle size. In terms of the gender of respondents the majority $(83 \%)$ was males and the rest were $(17 \%)$ were females.

\section{Results and Discussion}

The crucial assumptions in this research are that internal marketing components namely (selection and appointment (staffing), training and development, organizational support, incentives and motivation, and retention policy) influence job satisfaction and organizational commitment. A multiple regression modeling approach was proposed as an effective method for studying the relationships. As displayed in Table 1, the adjusted R2 is 0.651 , suggesting that the five internal marketing factors explain close to 65 per cent of the variance for the dimension of satisfaction. Specifically, other tables also act variables have a statistically significant effect on job satisfaction. Of these significant variables, selection and appointment, training and development, and organizational support appear to have the greatest impact on job satisfaction. In addition, it predicted that the influence of such factors (selection and appointment (staffing), training and development, organizational support, incentives and motivation, and retention policy) on job satisfaction would differ according to the personal variables, which are personal characteristics and (as shown in table 3). The results of the multiple regression analysis signal that there is variation in the effect of internal marketing factors on job satisfaction and empirical evidence in this research suggests that internal marketing factors have a significant degree of influence on job satisfaction and organizational commitment. This empirical evidence has provided significant support for the internal marketing literature, which substantively advocates that internal marketing factors have an impact on organizational commitment.

The results empirically substantiate that internal marketing factors play a fundamental role in the job satisfaction among Saudi teaching hospitals.

\subsection{Selection and appointment has a positive significant influence on physician job satisfaction}

The findings in table (3) provide significant support for the selection and appointment literature which advocates that selection and appointment have an influence upon Saudi teaching hospitals. As a consequence, the researcher is able to substantiate that selection and appointment has a significant influence on physician job satisfaction. These findings are also consistent with other research findings (for example, Che ha et al, 2007; Masroor and Fakir, 2009; Nittala and Kameswari, 2009; Ibrahim et al, 2010).

\subsection{Training and development has a positive significant influence on physician job satisfaction}

Training and development is also considered to be one of the influential factors on the job satisfaction of Saudi teaching hospitals (table 3). Prior research has empirically found positive relationship between training and development and job satisfaction as critical factors on the adoption of internal marketing concept (Che ha et al, 2007; Masroor and Fakir, 2009; Nittala and Kameswari, 2009; Ibrahim et al, 2010). In common condition the Saudi teaching hospitals consider the training and development as a win-win situation; this might impact positively on the physician's performance. As a result, the researcher is able to confirm that training and development have a significant influence on job satisfaction. These findings are also consistent with other research findings. For example, (Khan et al, 2011) found that internal marketing provides higher degree of training and development that enables physicians to improve their knowledge in both technically and functionally.

\subsection{Rewards and incentives systems has a positive significant influence on physician job satisfaction}

Examining data appears that a requirement for survival and growth is that both the hospitals and their staff, physicians in particular have an interest in their joint relationship - leading to a win-win effect. Factors such as rewards and incentives are playing a core role in enhancing the physician's satisfaction and commitment.

Rewards and incentives is important dimension that may affect physician's satisfaction to build their trust (Che ha et al, 2007). Rewards and incentives consider as one of the most influential factor on physician job satisfaction as shown in table (3).

\subsection{Organizational support has a positive significant influence on physician job satisfaction}

An examination of table (3) suggests that organizational support is an influential factor on job satisfaction in Saudi teaching hospitals. The results therefore, substantiate that organizational support has a positive bearing on job satisfaction. These findings are also consistent with other research findings. For example, (Che ha et al, 2007; Suzuki et al, 2006; Conduit and Mavondo, 2001) found that organizational support give an opportunities to the physicians that enables physicians to trust hospitals at all times. 


\subsection{Retention policy has a positive significant influence on physician job satisfaction}

Retention policy is also considered to be one of the influential factors on the physician job satisfaction of Saudi teaching hospitals (table 3). Prior research has empirically found positive relationship between retention policy and job satisfaction (Che ha et al, 2007; Suzuki et al, 2006; Nittala and Kameswari, 2009; Ibrahim et al, 2010). These results indicate that the retention policy is an important element to retain the qualified physicians in these hospitals, also this will be reflects on the physician and patient satisfaction.

In summary, it can be seen that all internal marketing factors, which selection and appointment (staffing), training and development, organizational support, incentives and motivation, and retention policy, have proven to positively physicians job satisfaction.

Examining data in tables $(4,5)$ it appear that physician job satisfaction has a positive significant influence on organizational commitment of adopting internal marketing concepts by Saudi teaching hospitals. This result was explained at in the proposed model ( $\mathrm{R} 2$ Job satisfaction $=0.476, \mathrm{R} 2$ Organizational commitment $=0.466$ ). Generally speaking, we can conclude that physician job satisfaction is a key mediating factor in the organizational commitment in the teaching hospital in KSA.

\section{Implications}

The theoretical keystone of this study is based on literature from the internal marketing relating to physicians and medical staff within the hospital industry. Health service marketing scholars and hospital executive officers have long since recognized the crucial of internal marketing in the health service industry could be very helpful by improving the job satisfaction of hospitals physicians. It will be beneficial to adopt more human resources practices in the internal marketing perspective. Moreover, teaching hospitals are considered as a high staff intensity service, involving very frequent encounter with patients, because their life and health are often in risk. Consequently, it is an essential that the physicians are satisfied so that they can provide high quality health services. The empirical conclusions drawn from this research are multifaceted and as a result, it is vitally important that hospital managers pay attention to the influences of internal marketing on physician job satisfaction. Researchers are therefore encouraged to place more focus on the impact influences stemming from the internal marketing application and its impact on physician job satisfaction and organizational commitment within Saudi teaching hospitals.

\section{Conclusions}

This research seeks to make an original contribution to knowledge by investigating the impact internal marketing factors on physician job satisfaction and organizational commitment in the teaching hospitals industry in KSA. This research contributes to the health services marketing and human resources discipline in finding out the role of the internal marketing in enhancing physician's job satisfaction and organizational commitment.

Factors pertaining to selection and appointment (staffing), training and development, organizational support, incentives and motivation, and retention policy were a focus of this study as they have an influence on physician's job satisfaction and organizational commitment. Contributions found will be beneficial for both academics and managers alike. Academically, this work aims to focus academic attention upon a much neglected domain - the health services marketing and human resources of teaching hospitals in KSA. There is currently a distinct lack of studies in academia relating to research in the Gulf and Middle East countries.

In fact, the health services industry is an important and vibrant sector in KSA and teaching hospitals are considered as an important segment of the health services provider where patients can receive a wide range of health services. Although this research has provided valuable insights into a somewhat scant area of research, it has been subject to some limitations. To begin with, there were some difficulties in the distribution of the research questionnaire within the physicians of Saudi teaching hospitals, possibly leading to some inconsistencies in the data collection process. For example, a part of teaching hospitals opted to distribute the instrument to respondents themselves, where in other cases the researcher delivered the survey to respondents individually. In addition, this research has been conducted within a single health service and exclusively in the teaching hospitals sector, thus limiting the generalisability of the research results to the other hospitals which classified as non-teaching hospitals in KSA. Also, this research has been conducted within single research respondents at the teaching hospitals exclusively the physicians at these hospitals, thus limiting the generalisability of the research results to the other employee. Future research is therefore required to extend these results in other sectors alike also to other employees at these hospitals. For example, the concept could be extended to other Arab countries in order to validate the model and findings. By studying other service and health sectors (for example, non teaching hospitals) a model could be developed to better represent the service sector in more general, rather than focusing on the teaching hospitals alone. The inclusion of employees at all teaching 
hospitals levels would allow for more insight to be gathered on employees' viewpoints, attitudes, perceptions and overall satisfaction and organizational commitment.

\section{References}

Armstrong, G., \& Kotler, P. (2011). Marketing-an Introduction: Global Edition (10th ed.). NJ: Pearson.

Berry, LL., Hensel, JS., \& Burke, MC. (1976). Improving retailer capability for effective consumerism response. Journal of Retail, 52(3), 3-14.

Bernstein, L. (2005). Internal marketing of an ED-based public health initiative. American Journal of Emergency Medicine, 23 (3), 411-413. http://dx.doi.org/10.1016/j.ajem.2005.02.026

Buchanan, B. (1974). Building organizational commitment: The socialization of managers in work organization. Administrative Science Quarterly, 19, 533-546. http://dx.doi.org/10.2307/2391809

Castle, G., Engberg, J., \& Anderson, A. (2007). Job satisfaction of nursing home administrators and turnover. Medical Care Research and Review, 64 (2), 191-211. http://dx.doi.org/10.1177/1077558706298291

Che Ha, Abu Bakar \& Jaafar, J. (2007). Internal marketing issues in service organizations in Malaysia", International Review of Business Research Papers, 3 (5), 134-145.

Chen, C., Lin, YH., \& Ho, CS. (2006). Research on the relationship between internal marketing and medical personnel's turnover intension in the situation of a dangerous outbreak of illness like SARS. A regional Hospital for example. Cheng Chin Medical Journal, 2(4), 28-36.

Conduit, J., Mavondo, FT. (2001). How critical is internal customer orientation to market orientation. Journal of Business Research, 51(1), 11-24. http://dx.doi.org/10.1016/S0148-2963(99)00044-2

Dee, J. R., Henkin, A. B., \& Singleton, C. A. (2006). Organizational commitment of teachers in urban schools Examining the effects of team structures. Urban Education, 41 (6), 603-627. http://dx.doi.org/10.1177/0042085906292512

Greene, E., Walls, D., \& Schrest, J. (1994). Internal marketing - The key to external marketing success. Journal of Service Marketing, 8 (4), 5-13. http://dx.doi.org/10.1108/08876049410070682

Grönroos, C. (1984). A service quality model and its marketing implications. European Journal of Marketing , 18(4), 36-44. http://dx.doi.org/10.1108/EUM0000000004784

Grönroos, C. (1981). Internal marketing an integral part of marketing theory. In Marketing of Services. Edited by Donnelly JH Jr, George WR. Chicago: American Marketing Association; 236-238.

Grönroos, C. (1985). Internal marketing theory and practice in services marketing in a changing environment. Bloch, T.M. (EDS). American Marketing Association: Chicago, $42-47$.

Ibrahim et al (2010). The Effect of Internal Marketing Implementation on Job Satisfaction of Sales People in Jordan Telecom Group '1 in Retail Sector, 3 (3). 207-220.

Kameswari, A., \& Rajyalakshmi, S. (2012). Role of internal marketing in job satisfaction of employees in commercial bank, Asian Journal of Research in Banking and Finance, 2 (7), 16-32.

Karthikeyan, K., Karthi, R. \& Shyamala, D. (2010). Impact of training in Indian banking sector - an empirical investigation", International Journal of Business and Management, 5 (7).

Khan, M., Ur-Rehman, A., Safwan, I., \& Ashfaq, A. (2011). Modeling link between internal service quality in human resources management and employees retention: A case of Pakistani privatized and public sector banks, African Journal of Business Management, 5 (3), 949-959.

Kotler, P. (1991). Marketing management - Analysis, planning, implementation and control. 7th edition. Englewood Cliffs, NJ: Prentice Hall.

Kotler P. (1994). Marketing management. Eaglewood Cliffs, NJ: Prentice Hall, Management Executive, 13(2). 41-43.

Lambert, G., Pasupuleti, S., Cluse-Tolar, T., Jennings, M., \& Baker, D. (2006). The impact of work-family conflict on social work and human service worker job satisfaction and organizational commitment: An exploratory study. Administration in Social Work, 30 (3), 55-74. http://dx.doi.org/10.1300/J147v30n03_05 
Longbottom, D., Osseo-Asare, E., Chourides, P., \& Murphy, W. D. (2006). Real quality: Does the future of TQM de- pend on internal marketing? Total Quality Management \& Business Excellence, 17 (6), 709-732. http://dx.doi.org/10.1080/14783360600594370

Masroor, M., Faki, J. (2009). Level of job satisfaction and intent to leave among Malaysian nurses, Business Intelligence Journal, January, 123 - 137.

Paulin, M., Ronald, J., \& Bergeron, J. (2006). Service climate and organizational commitment: The importance of customer linkages". Journal of Business Research, 59, 906- 915. http://dx.doi.org/10.1016/j.jbusres.2006.03.004

Moss, A., McFarland, J., Ngu, S., \& Kijowska, A. (2007). Maintaining an open mind to closed individuals: The effect of resource availability and leadership style on the association between openness to experience and organizational commitment. Journal of Research in Personality, 41(2), 259-275. http://dx.doi.org/10.1016/j.jrp.2006.03.009

Naude, P., Desai, J., \& Murphy, J. (2003). Identifying the determinants of internal marketing orientation, European Journal of Marketing, 37 (9), 1205-1220. http://dx.doi.org/10.1108/0390560310486951

Nebeker, D., Busso, L., Werenfels, P.D., Diallo, H., Czebajewski, A., \& Ferdman, B. (2001). Performance as a function of employee satisfaction. Journal of Quality Management 6, 29-45. http://dx.doi.org/10.1016/S1084-8568(01)00027-X

Nelson, B. (2006). Employee satisfaction essential to commitment. Health Care Register: The News for Health Care Register Professional, 15(9), 3-4.

Panigyrakis, G. and Theodoridis, K. (2009). Internal marketing impact on business performance in a retail context, International Journal of Retail \& Distribution Management, $37 \quad(7), \quad 600 \quad-\quad 628$. http://dx.doi.org/10.1108/09590550910964620

Pawan, S., Arup, V., Neeru, M., Mukherjee, J. (2009) "Insights into the Indian call centre industry: can internal marketing help tackle high employee turnover? Journal of Services Marketing, 23 (5), 351 - 362. http://dx.doi.org/10.1108/08876040910973459

Pfeffer, J., \& Sutton, I. (1999). Knowing 'what' to do is not enough: turning knowledge into action, California Management Review, 42 (1), 83-108.

Rafiq M, Ahmed P. (2000). Advances in the internal marketing concept: definition, synthesis and extension. Journal of Services Marketing, 14(6), 449-462. http://dx.doi.org/10.1108/08876040010347589

Porter, L. W., \& Lawler, E. E. (1968). What job attitudes tell about motivation. Harvard Business Review, 46 (1), $118-126$.

Porter, W., Steer, M., Mowday, T., \& Boulian, V. (1974). Organizational commitment, job satisfaction, and turnover among psychiatric technicians. Journal of Applied Psychology, 59, 603-609. http://dx.doi.org/10.1037/h0037335

Preston, J. \& Steel, L. (2002). Internal marketing strategies in LIS: a strategic management perspective", Library Management, 23 (6/7), 294 - 301. http://dx.doi.org/10.1108/01435120210432264

Rajyalakshmi, N., \& Kameswari, V. (2009). Internal marketing for customer satisfaction retail context, International Journal of Retail \& Distribution Management; 37 (7), 600-628.

Robbins, P. (1996). Organization behavior: Concept, controversies, and applications. Englewood Cliffs, NJ Prentice-Hall

Sang, K., Ison, S., \& Dainty, A. (2009). The job satisfaction of UK architects and relationships with Services Marketing, 23 (5) 351-362.

Shiu, M., \& Yu, T. (2010). Internal marketing, organisational culture, job satisfaction, and organisational performance in non-life insurance. The Service Industry Journal, 30(6), 793-809. http://dx.doi.org/10.1080/02642060701849840

Shimizu, T., Feng, L., \& Nagata, S. (2005). Relationship between turnover and burnout among Japanese hospital nurses. Journal of Occupational Health, 47 (4), 334-336. http://dx.doi.org/10.1539/joh.47.334

Shimizu, T., Eto, R., Horiguchi, I., Obata, Y., Feng, Q. L., \& Nagata, S. (2005). Relationship between turnover and periodic health check-up data among Japanese hospital nurses: A three-year follow-up study. Journal of Occupational Health, 47 (4), 327-333. http://dx.doi.org/10.1539/joh.47.327 
Suzuki, E., Itomine, I., Kanoya, Y., Katsuki, T., Horii, S., \& Sato, C. (2006). Factors affecting rapid turnover of novice nurses in university hospitals. Journal of Occupational Health, 48 (1), 49-61. http://dx.doi.org/10.1539/joh.48.49

Tadeka, F., Ibaraki, N., Yokoyama, E., Miyake, T., \& Ohida, T. (2005). The relationship of job type to burnout in social workers at social welfare offices. Journal Occupational Health, 47(2) 119-125. http://dx.doi.org/10.1539/joh.47.119

Tansuhaj, P., Randall, D., and McCullough, J. (1991). Applying the internal marketing concept within large organizations: as applied to a Credit Union. Journal of Professional Services marketing, 6 (2), 193-202. http://dx.doi.org/10.1300/J090v06n02_14

Yavas, U., \& Emin, B. (2010). Relationships between organizational support, customer orientation, and work outcomes - A study of frontline bank employees, International Journal of Bank Marketing, 28 (3), 222-238. http://dx.doi.org/10.1108/02652321011036477

Walter, E., \& Greene, Gary, D., \& Larry J. (1994). Internal marketing the key to external marketing success", Journal of Services Marketing, 8 (4), 5-13. http://dx.doi.org/10.1108/08876049410070682

Whyte, W. (1956). The organization man. Garden City, NY:Doubledy Anchor.

Yavas, U \& Babakus, E. (2010). Relationships between organizational support, customer orientation, and work outcomes: a study of frontline bank employees, International Journal of Bank Marketing, 28 (3), 222 - 238. http://dx.doi.org/10.1108/02652321011036477

Yavas, U., Karatepe, O.M., Avci, T., \& Tekinkus, M. (2003). Antecedents and outcomes of service recovery performance: An empirical study of frontline employees in Turkish banks". The International Journal of Bank Marketing 21 (5), 255-265. http://dx.doi.org/10.1108/02652320310488439

Yang, H., \& Coates, N. (2010). Internal marketing: service quality in leisure services, Marketing Intelligence \& Planning, 28 (6), 754 - 769. http://dx.doi.org/10.1108/02634501011078147

Zeithaml, V. A., \& Bitner, M. J. (2000). Services marketing (7th ed.). New York: McGraw-Hill. 
Table 1. IM (selection and appointment (staffing), training and development, organizational support, incentives and motivation, and retention policy)

IM Factors: Independent variables

\section{Selection and appointment (staffing) (independent variable)}

The hospital management is keen to place me in a job position that is appropriate with my specialization, The hospital management is keen to attract employees who possess the ability to deal with customers/and patients, The hospital is keen to follow specific procedures and objectives selection and appointment of staff, The hospital management is keen to hire workers who have the skills and capabilities necessary for the provision of health services quality, Management feels that the hospital hire me was the right decision, The hospital is keen to provide a suitable working environment.

\section{Training and development (independent variable)}

Our hospital working on the development of its staff to achieve better performance, Our hospital considers develop knowledge and skills of staff as an investment, The process of developing the knowledge and skills of staff is an ongoing process in our hospital, The hospital is keen on the education of its employees "Why are they doing this" and not just "how to accomplish these acts", In our hospital staff receive training to be able to perform the health service correctly, This hospital is highly flexible deal in meeting the different needs of staff.

\section{Organizational support ((independent variable)}

My achievements appreciated by hospital's management, Hospital management gives me opportunities for promotion, Hospital management interested in my suggestions leading to change the working environment, Hospital management wishes to give me a better business that is likely to be efficient in the delivery, The hospital management is trying hard to make my work enjoyable as possible, Supervisors and direct managers are proud that I am part of this hospital.

\section{Incentives and Motivations System (independent variable)}

The measurement system of performance and incentives in the hospital encouraged to work well, The hospital is keen to measure and reward employee performance that contributes to achieving its vision, The hospital depends on the use of data and information collected from staff to improve their jobs, The hospital informs the staff of the importance of service roles that they do, Hospital staff that provide excellent services, they will get a good reward.

\section{Retention policy (independent variable)}

If the hospital can to attract new employees and pay less than my position, it will not do so, Hospital management show great interest of me, If I decided to resign, the hospital management will convince me to stay, The hospital management is interested in the payment of salary, which I deserved.

Table 2. Job Satisfaction: (dependent variable)

Physician's job satisfaction in the Saudi teaching sector hospitals was measured on:

I'm satisfied with overall job, I'm satisfied with supervisor(s), I'm satisfied with the hospital's policies, I'm satisfied with support from the hospital, I'm satisfied with opportunities for advancement.

Organizational Commitment: (dependent variable)

Organizational commitment in the Saudi teaching sector hospitals was measured on:

I would be very happy to spend the rest of my career with this hospital, I enjoy discussing my hospital with people outside of it, I really feel as if this hospital's problems are my own, I think that I could easily become as attached to another hospital as I am to this one, I do not feel like "part of the family" at my hospital, I do not feel "emotionally attached" to this hospital, This hospital has a great deal of personal meaning for me.

Table 3. Results -Internal Marketing factors (Physician Job Satisfaction)

\begin{tabular}{llllll}
\hline IM & $\mathrm{B}$ & Standardized error & Beta & t-value & Significant \\
\hline IM & 0.677 & 0.312 & 0.273 & 3.237 & 0.004 \\
Selection and appointment & 0.761 & 0.461 & 0.288 & 3.546 & 0.000 \\
Training and development & 0.744 & 0.487 & 0.257 & 3.876 & 0.001 \\
Organizational support & 0.613 & 0.389 & 0.267 & 3.190 & 0.001 \\
Incentives and motivation & 0.653 & 0.344 & 0.256 & 3.122 & 0.036 \\
retention policy & 0.611 & 0.472 & 0.207 & 2.981 & 0.041 \\
\hline
\end{tabular}

Note: $\mathrm{R} 2=0.571 ;$ Adjusted R $2=0.651 ; \mathrm{F}=10.650 ; \mathrm{P}<0.05$. 
Table 4. Results -Physician Job Satisfaction (Organizational Commitment)

\begin{tabular}{llllll}
\hline Physician Job Satisfaction & B & Standardized error & Beta & t-value & Significant \\
\hline Physician Job Satisfaction & 0.564 & 0.355 & 0.219 & 3.177 & 0.006
\end{tabular}

Note: $\mathrm{R} 2=0.401 ;$ Adjusted R $2=0.476 ; \mathrm{F}=9.760 ; \mathrm{P}<0.05$.

Table 5. Results -IM (Organizational Commitment)

\begin{tabular}{llllll}
\hline IM & B & Standardized error & Beta & t-value & Significant \\
\hline IM & 0.588 & 0.361 & 0.222 & 3.298 & 0.011 \\
\hline
\end{tabular}

Note: $\mathrm{R} 2=0.441 ;$ Adjusted R $2=0.466 ; \mathrm{F}=9.360 ; \mathrm{P}<0.05$.

Table 6. Characteristics of the Sample $(\mathrm{N}=230)$

\begin{tabular}{|l|l|l|}
\hline Characteristics & \% & \\
\hline 1.1 Age & 0 & \\
Under 30 & 15 & \\
$30-40$ & 80 & \\
$41-50$ & 4 & \\
$51-60$ & 1 & \\
over 60 & & \\
\hline 1.2 Gender & 83 & \\
Male & 17 & \\
Female & & \\
\hline 1.3 Nationality & 80 \\
Saudi & 20 & \\
Non-Saudi & & \\
\hline 1.4 Educational Level & 70 & \\
Bachelor's degree & 25 & \\
Masters degree & 5 & \\
Doctoral degree & 0 & \\
Other, please specify........ & & \\
\hline 1.5 Number of years you have been & & \\
working in the health services sector & & \\
Less than 5 & 0 & \\
5-9 & 2 & \\
10-15 & 8 & \\
16-20 \\
over 20 & 75 & \\
\hline 1.6 Occupational Level & 15 & \\
Consultant & 40 & \\
Specialist & 52 & \\
General Practitioner & 8 & \\
Other, please specify & 0 & \\
\hline 1.7 Hospital Size & & \\
Larg (300 or more than beds) & 10 & \\
Medi (101-299 beds) & 0 & \\
Fs (100 and less) & & \\
& & \\
\hline
\end{tabular}




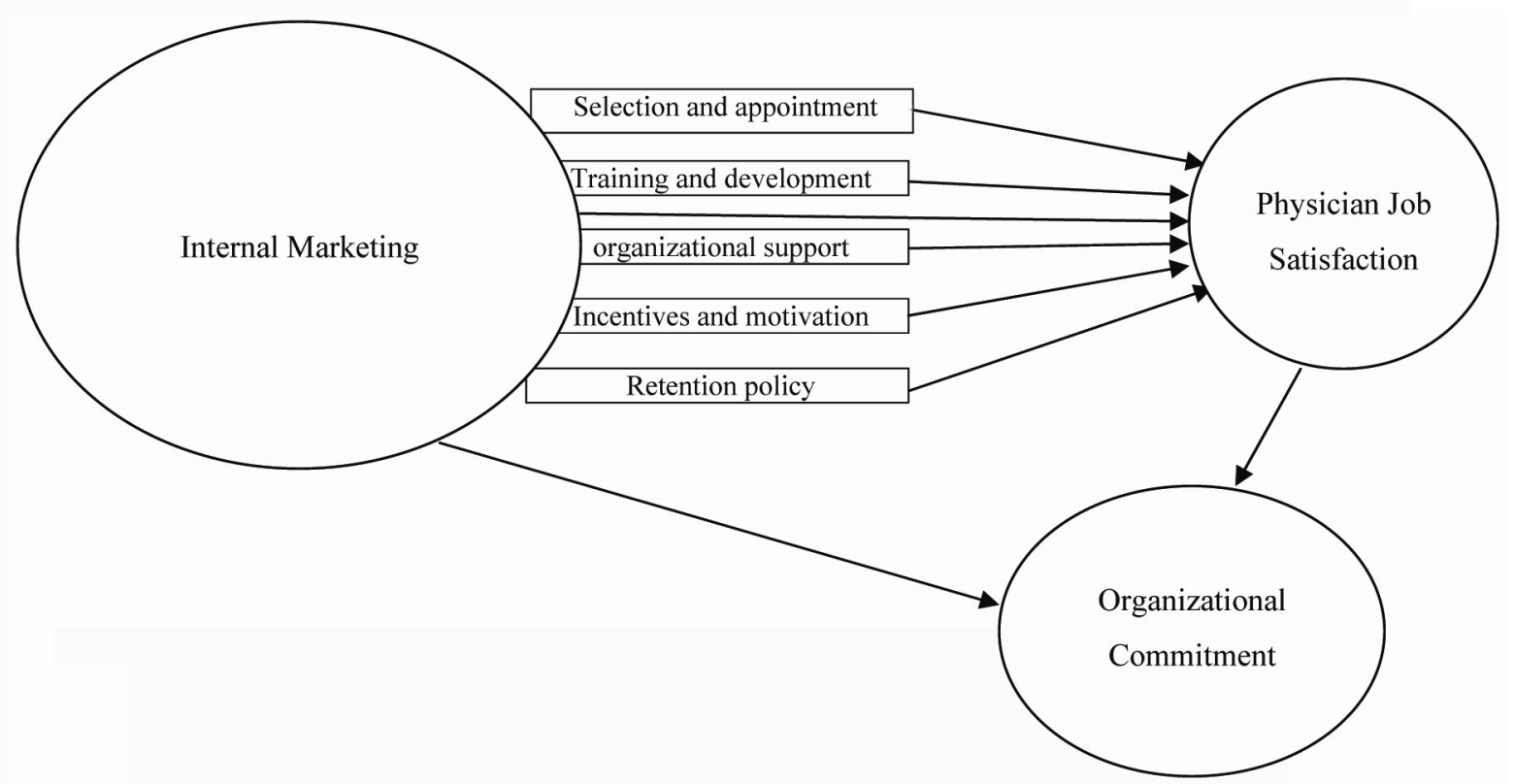

Figure 1. Research Model 